\title{
Constitutional Question: \\ Latar Belakang dan Praktik Di Negara Lain Serta Kemungkinan Penerapannya Di Indonesia
}

\author{
I Dewa Gede Palguna \\ Fakultas Hukum Universitas Udayana Bali \\ Jl. Pulau Bali No. 1 Denpasar Bali 80114 \\ idgpalguna@artifoundation.org
}

\begin{abstract}
The adoption of constitutional question mechanism in the constitution court system, (known as constitutional adjudication), regarded as part of providing a maximum protection to the citizen's constitution rights. The kind of protection is a must-have entity in every law-based nation (in the democratic system). For Indonesia, which has ambition to establish a democracy-based life along with law-based life, as been said in Article 1 Section 2 and 3 in 1945 Constitution, the consideration for adopting a mechanism of "constitutional question" is not impossible to happen. Even more, logically, it is a need.
\end{abstract}

Key word $\quad$ : constitutional question, Constitutional Court of Law, Law-Based nation, Indonesia.

\begin{abstract}
Abstrak
Diadopsinya mekanisme constitutional question dalam sistem peradilan konstitusi (constitutional adjudication) adalah sebagai bagian dari pemberian perlindungan maksimum terhadap hak-hak konstitusional warga negara. Perlindungan demikian merupakan syarat yang tak dapat ditiadakan dalam setiap negara hukum (yang demokratis). Bagi Indonesia, yang juga hendak mewujudkan kehidupan bernegara yang demokratis dan sekaligus negara hukum, sebagaimana ditegaskan oleh Pasal 1 ayat (2) dan (3) UUD 1945, mempertimbangkan untuk mengadopsi mekanisme constitutional question bukanlah sesuatu yang mengada-ada. Bahkan, secara logis, justru suatu kebutuhan.
\end{abstract}

Kata kunci : constitutional question, Mahkamah Konstitusi, Negara Hukum, Indonesia 


\section{Pendahuluan}

Istilah constitutional question mengandung dua pengertian, umum dan khusus. Dalam pengertian yang umum, constitutional question adalah istilah yang merujuk pada setiap persoalan yang berkaitan dengan konstitusi (dan yang lazimnya merupakan kewenangan Mahkamah Konstitusi untuk memutusnya). ${ }^{1}$ Sedangkan dalam arti khusus, constitutional question adalah merujuk pada suatu mekanisme pengujian konstitusionalitas undang-undang di mana seorang hakim (dari regular courts) yang sedang mengadili suatu perkara menilai atau ragu-ragu akan konstitusionalitas undang-undang yang berlaku untuk perkara itu, maka ia mengajukan "pertanyaan konstitusional" ke Mahkamah Konstitusi (mengenai konstitusional-tidaknya undang-undang itu). Mahkamah Konstitusi hanya memutus persoalan konstitusionalitas undang-undang itu, jadi bukan memutus kasus itu sendiri, namun selama Mahkamah Konstitusi belum menyatakan putusannya, pemeriksaan terhadap kasus tersebut dihentikan. ${ }^{2}$

Sejarah kelahiran constitutional question tidak terlepas dari sejarah kelahiran Mahkamah Konstitusi. Sebagaimana diketahui, ide membentuk Mahkamah Konstitusi mula pertama digagas oleh Hans Kelsen setelah berakhirnya Perang Dunia I, yang antara lain diikuti oleh runtuhnya kekaisaran Austro-Hungaria dan berdirinya Republik Austria. Di republik yang baru terbentuk ini Hans Kelsen diangkat menjadi Chancelery yang bertugas menyusun konstitusi dalam rangka pembaruan konstitusi Austria (1919-1920). ${ }^{3}$ Di sinilah Kelsen mengemukakan gagasannya tentang perlunya Austria memiliki Mahkamah Konstitusi (yang terpisah dari sistem peradilan biasa) yang fungsinya adalah untuk menegakkan konstitusi dengan kewenangan utama membatalkan undang-undang jika undang-undang itu bertentangan dengan konstitusi. ${ }^{4}$

\footnotetext{
${ }^{1}$ Lihat misalnya Donald P. Kommers, The Constitutional Jurisprudence of the Federal Republic of Germany, Durham and London, Duke University Press, 1989, hlm. 1.

${ }^{2}$ Victor Ferreres Comella, "Is the European Model of Constitutional Review in Crisis", paper presented for the $12^{\text {th }}$ Annual Conference on 'the Individual V s. the State', Central European University, Budapest, June 18-19, 2004, hlm. 4.

${ }^{3}$ Lihat Herbert M. Kritzer (ed.), Legal Systems of the World, A Political, Social and Cultural Encyclopedia, Volume I: A-D, New Delhi, Pentagon Press, 2005, hlm. 93. Jimly Asshiddiqie, Model-model Pengujian Konstitusional Di Berbagai Negara, Cetakan Kedua, Jakarta, Konpres, 2005, hlm. 34; Herman Schwartz, The Struggle for Constitutional Justice in PostCommunist Europe, Chicago and London, the University of Chicago Press, 2000, hlm. 17; Mauro Cappelletti, The Judicial Process in Comparative Perspective, Oxford, Clarendon Press, 1989, hlm. 136; Michael Green, "Hans Kelsen and the Logic of Legal System” dalam Alabama Law Review Volume 54, Number 2, Winter 2003, hlm. 385.

${ }^{4}$ Herman Schwartz, Loc.Cit.
} 
Dengan demikian, fungsi Mahkamah Konstitusi adalah melaksanakan constitutional review. ${ }^{5}$ Sedangkan constitutional review - yang merupakan produk sistem pemerintahan modern yang dilandasi oleh gagasan negara hukum (rule of law), pemisahan kekuasaan (separation of powers), dan perlindungan terhadap hak asasi manusia (protection of fundamental rights) - memiliki dua tugas utama. Pertama, menjaga berfungsinya proses-proses demokrasi dalam hubungan saling mempengaruhi antara lembaga legislatif, eksekutif, dan yudikatif. Dengan kata lain, constitutional review bertugas mencegah perebutan kekuasaan oleh salah satu cabang kekuasaan negara dengan mengorbankan cabang-cabang kekuasaan negara lainnya. Kedua, yang tidak kalah pentingnya dan berkait erat dengan tugas pertama itu, adalah untuk melindungi hak-hak atau kehidupan pribadi warga negara dari pelanggaran yang dilakukan oleh salah satu cabang kekuasaan negara. ${ }^{6}$

Jadi, secara singkat dapat dikatakan bahwa gagasan membentuk Mahkamah Konstitusi adalah upaya untuk menegakkan prinsip-prinsip negara hukum dan memberi perlindungan maksimum terhadap demokrasi dan hak-hak dasar warga negara. ${ }^{7}$ Perlindungan terhadap hak-hak dasar ini menjadi penting digarisbawahi dalam setiap negara hukum (yang demokratis) - yang menempatkan konstitusi sebagai hukum tertinggi di negara yang bersangkutan - karena tatkala hak-hak dasar itu dimasukkan ke dalam konstitusi, yang berarti telah menjadi bagian dari konstitusi, maka ia mengikat seluruh cabang kekuasaan negara. ${ }^{8}$ Hal ini juga dapat dilihat dari perspektif lain, yaitu dari perspektif sejarah kelahiran pemikiran tentang konstitusi itu sendiri yang secara esensial tidak lain merupakan sejarah pernyataan hak-hak, sehingga hak-hak konstitusional itu sesungguhnya bukan sekadar berhubungan dengan konstitusi melainkan merupakan bagian dari (incorporated in) konstitusi. ${ }^{9}$

Berdasarkan pengantar singkat di atas jelaslah bahwa diadopsinya mekanisme constitutional question dalam sistem peradilan konstitusi (constitutional adjudication)

\footnotetext{
${ }^{5}$ Lebih jauh mengenai pasang-surut perkembangan gagasan tentang constitutional review ini, lihat, antara lain, Jimly Asshiddiqie, 2005, Model-model Pengujian Konstitusional..., Op.Cit., hlm.1-47.

${ }^{6} \mathrm{H}$. Hausmaninger, The Austrian Legal System, Wien, Manzsche Verlags- und Universitätsbuchhandlung, 2003, hlm. 139.

${ }^{7}$ Trevor L. Brown \& Charles R. Wise, "Constitutional Courts and Legislative-Executive Relations: The Case of Ukraine", Political Science Quarterly, Vol. 119, No. 1, 1994, hlm. 155. Lihat juga John Ferejohn \& Pasquale Pasquino, "Rule of Democracy and Rule of Law" dalam Josë María Maravall \& Adam Przeworski, Democracy and Rule of Law, Cambridge, University Prees, 2003, hlm. 251.

${ }^{8}$ Lihat lebih jauh Durga Das Basu, Human Rights in Constitutional Law, Wadhwa and Company, New DelhiNagpur-Agra, 2003, khususnya hlm. 48-78 dan hlm. 107-135.

${ }^{9}$ Ernest Baker, Reflection on Government, Oxford, Oxford University Press, 1958, hlm. 30-31.
} 
adalah sebagai bagian dari pemberian perlindungan maksimum terhadap hak-hak konstitusional warga negara. Perlindungan demikian merupakan syarat yang tak dapat ditiadakan dalam setiap negara hukum (yang demokratis). Sehingga tidaklah berlebihan jika Donald Horowitz mengatakan bahwa melalui kewenangan untuk mengadili masalah-masalah yang berkait dengan konstitusi, sekaligus kewenangan untuk "memaksakan" pentaatan terhadap konstitusi, Mahkamah Konstitusi telah menjadikan konstitusi benar-benar sebagai dokumen yang hidup (a living document) yang memberi bentuk dan arah kekuasaan politik dalam suatu negara, bukan sekadar kumpulan kalimat-kalimat simbolik atau aspirasional. Dengan cara demikian, Mahkamah Konstitusi memberi kontribusi besar bukan hanya bagi terciptanya kehidupan bernegara yang berdasar atas hukum tetapi juga bagi demokrasi. ${ }^{10}$

Bagi Indonesia, yang juga hendak mewujudkan kehidupan bernegara yang demokratis dan sekaligus negara hukum, sebagaimana ditegaskan oleh Pasal 1 ayat (2) dan (3) UUD 1945, mempertimbangkan untuk mengadopsi mekanisme constitutional question bukanlah sesuatu yang mengada-ada. Bahkan, secara logis, justru suatu kebutuhan.

\section{Praktik Di Jerman}

Ada sejumlah negara yang mempraktikkan mekanisme constitutional question dalam sistem ketatanegaraannya, yaitu Jerman, Austria, Belgia, Itali, Luxemburg, dan Spanyol. ${ }^{11}$ Namun di antara negara-negara tersebut Jermanlah yang dianggap paling menonjol dan paling berpengaruh, bukan saja di kalangan negara-negara di kawasan Eropa, tetapi juga di Asia, Amerika Latin, dan Afrika. Karena alasan itulah maka tulisan ini hanya akan menyoroti praktik yang berkembang di Mahkamah Konstitusi Federal Jerman (Bundesverfassungsgericht, selanjutnya disebut MK Jerman). Di samping itu, keterbatasan waktu (terutama untuk mencari referensi serta untuk menulis) dan ruang juga menjadi alasan lain mengapa tulisan ini hanya akan menyoroti constitutional question yang diterapkan di Jerman.

${ }^{10}$ Donald L. Horowitz, "Constitutional Courts: A Primer for Decision Makers" dalam Journal of Democracy, Volume 17, Number 4, October 2006, hlm. 126.

${ }^{11}$ Lihat Victor Ferreres Comella, “The Conssequences of Centralizing Constitutional Review in A Special Court: Some Thoughts on Judicial Activism" dalam http://www.utexas.edu/law/journals/tlr/abstracts/82/ 82ferreres.pdf 
Kewenangan MK Jerman untuk mengadili perkara constitutional question (yang di Jerman disebut Konkrete Normenkontrolle atau Concrete Judicial Review (pengujian norma hukum secara konkret) ${ }^{12}$ diatur dalam Konstitusi Federal Jerman (Grundgesetz, selanjutnya disingkat GG) dan Undang-Undang tentang Mahkamah Konstitusi Federal Jerman (Bundesverfassungsgerichtsgesets, yang untuk selanjutnya disingkat BVerfGG). Berdasar pada Pasal 93 dan Pasal 100 GG, MK Jerman memiliki kewenangan yang luas, mencakup semua masalah mengenai pelaksanaan dan penafsiran GG. Sebab, MK Jerman memiliki kewenangan eksklusif terhadap semua proses peradilan yang secara langsung tercakup ke dalam persoalan ketaatan terhadap Konstitusi (GG). ${ }^{13}$ Pasal 93 ayat (1) GG tersebut selengkapnya menyatakan:14

The Federal Constitutional Court decides:

1. on the interpretation of this Constitution in the event of disputes concerning the extent of the rights and duties of a highest federal body or other parties concerned who have been vested with rights of their own by this Constitution or by rules of procedure of a highest federal body;

2. in case of differences of opinion or doubts on the formal and material compatibility of federal law or State law with this Constitution, or on the compatibility of State law with other federal law, at the request of the Government, of a State government, or of one third of the House of Representatives [Bundestag] members;

2a. in case of differences of oninion on the compatibility of federal law with Article 72 II, at the request of the Senate [Bundesrat], of a State government, or of a State parliament;:15

3. in case of differences differences of opinion on the rights and duties of the Federation and the States [Lander], particularly in the execution of federal law by the States [Lander] and in the exercise of federal supervision;

4. on other disputes involving public law, between the Federation and the States [Lander], between different States [Lander] or within a State [Land], unless recourse to another court exists;

4a. on complaints of unconstitutionality, being filed by any person claiming that one of his basic rights or one of his rights under Article 20 IV or under Article 33, 38, 101, 103 or 104 has been violated by public authority; ${ }^{16}$

$4 b$. on complaints of unconstitutionality filed by communes or associations of communes on the ground that their right to self-government under Article 28 has been violated by a statute other than a State statute open to complaint to the respective State constitutional court, ${ }_{1}^{17}$

5. in other cases provided for in this Constitution.

\footnotetext{
${ }^{12}$ Sering juga disebut "Richtervorlage" (judicial reference); David P. Currie, The Constitution of the Federal Republic of Germany, Chicago and London, the University of Chicago Press, 1994, hlm. 28.

${ }^{13}$ Dieter Blumenwitz, "The Federal Constitutional Court of Germany and Foreign Affairs. An Introduction for the American Reader to the Court Decision of July 31, 1973" dalam Frederick W. Hess (Ed.), German Unity, Documentation and Commentaries on the Basic Treaty, East Europe Monograph 4, Park College, Govermental Research Bureau: Kansas City-Missouri, h. 11. Lihat juga David P. Currie, Op.Cit., hlm. 27.

${ }^{14}$ Untuk uraian berikut, lihat juga tulisan Penulis, 2008, Mabkamah Konstitusi, Judicial Review, dan Welfare State, Sekretariat Jenderal dan Kepaniteraan Mahkamah Konstitusi RI, Jakarta, hlm. 132-139.

${ }^{15}$ Ketentuan pada Ayat (1) 2.a ini dimasukkan pada Amandemen ke-42 (27 Oktober 1994); vide Axel Tschentscher, 2002, The Basic Law (Grundgesetz), Jurisprudentia Verlag, Würzburg, hlm. 72.

${ }^{16}$ Ayat ini dimasukkan pada Amandemen ke-19 (29 Januari 1969); Ibid., hlm. 73.

${ }^{17}$ Ayat ini dimasukkan pada Amandemen ke-19 (29 Januari 1969); Ibid.
} 
Sementara itu, ketentuan GG yang secara langsung memberikan kewenangan kepada MK Jerman untuk memutus perkara constitutional question (Konkrete Normenkontrolle atau Concrete Judicial Review) adalah Pasal 100 yang berbunyi:

(1) If a court considers that a statute on whose validity the court's decision depends is unconstitutional, the proceedings shall be stayed, and a decision shall be obtained from the Land court with jurisdiction over constitutional disputes when the constitution of a Land is held to be violated, or from the Federal Constitutional Court when this Basic Law is held to be violated. This shall also apply when the Basic Law is held to be violated by Land law or where a Land statute is held to be incompatible with a federal statute.

(2) If, in the course of litigation, doubt exists whether a rule of public international law is an integral part of federal law and whether such rule directly creates rights and duties for the individual (Article 25), the court shall obtain a decision from the federal Constitutional Court.

(3) If the constitutional court of a Land, in interpreting this Basic Law, intends to deviate from a decision of the Federal Constitutional Court or of the constitutional court of another Land, is shall obtain a decision from the Federal Constitutional Court.

Kemudian, dengan berdasar pada ketentuan Pasal 93 Ayat (2) GG (yang memberikan kemungkinan kepada MK Jerman untuk juga memperoleh kewenangannya berdasarkan undang-undang federal), ${ }^{18}$ kewenangan MK Jerman untuk memutus perkara constitutional question ditegaskan dalam Pasal 13 BVerfGG angka 11, 12, dan 13. Pasal 13 BVerfGG selengkapnya menyatakan:

The Federal Constitutional Court shall decide:

1. on the forfeiture of basic rights (Article 18 of the Basic Law);

2. on the unconstitutionality of parties (Article 21 (2) of the Basic Law);

3. on complaints against decisions of the Bundestag relating to the validity of an election or to the acquisition or loss of a deputy's seat in the Bundestag (Article 41 (2) of the Basic Law);

4. on the impeachment of the Federal President by the Bundestag or the Bundesrat Article 61 of the Basic Law);

5. on the interpretation of the Basic Law in the event of disputes concerning the extent of the rights and duties of a supreme Federal organ or of other parties concerned who have been vested with rights of their own by the Basic Law or by rules of procedure of a supreme Federal organ (Article 93 (1) (1) of the Basic Law);

6. in case of disagreements or doubt on the formal and material compatibility of Federal law or Land law with the Basic Law, or on the compatibility of Land law with other Federal law, at the request of the Federal Government, of a Land government, or of one third of the Bundestag members (Article 93 (1) (2) of the Basic Law);

7. in case of disagreements on the rights and duties of the Federation and the Lander, particularly in the implementation of Federal law by the Lander and in the exercise of Federal supervision (Article 93 (1) (3) and Article 84 (4), second sentence, of the Basic Law);

\footnotetext{
${ }^{18}$ Pasal 93 ayat (2) GG menyatakan, "The Federal Constitutional Court shall also act in such other cases as may be assigned to it by federal legislation"
} 
8. on other disputes involving public law, between the Federation and the Lander, between different Lander or with a Land, unless recourse to another court exists (Article 93 (1) (4) of the Basic Law);

$8 a$. on constitutional complaints (Article 93 (1) (4a) and (4b) of the Basic Law);

9. on the impeachment of Federal and Land judges (Article 98 (2) and (5) of the Basic Law); 10. on the constitutional disputes within a Land if such decision is assigned to the Federal Constitutional Court by Land legislation (Article 99 of the Basic Law);

11. on the compatibility of a Federal or Land law with the Basic Law or the compatibility of a Land statute or other Land law with a Federal law, when such decision is requested by a court (Article 100 (1) of the Basic Law);

12. in case of doubt whether a rule of public international law is an integral part of Federal law and whether such rule directly creates rights and duties for the individual, when such decision is requested by a court (Article 100 (2) of the Basic Law);

13. if the constitutional court of a Land, in interpreting the Basic Law, intend to deviate from a decision of the Federal Constitutional Court or of the constitutional court of another Land, when such decision is requested by that constitutional court (Article 100 (3) of the Basic Law);

14. in case of disagreement on the continuance of law as Federal law (Article 126 of the Basic Law);

15. in such other cases as are assigned to it by Federal legislation (Article 93 (2) of the Basic Law): $;^{19}$

Setelah memperhatikan ketentuan Pasal 93 ayat (1) angka 5, Pasal 93 ayat (2), Pasal 100 GG serta Pasal 13 angka 11, 12, dan 13 BVerfGG di atas, ada beberapa hal yang penting untuk digarisbawahi:

a. Persoalan constitutional question muncul jika:

1) suatu pengadilan menganggap bahwa suatu undang-undang tidak konstitusional, baik tidak konstitusional dengan konstitusi Negara Bagian (Land) maupun dengan konstitusi Federal (GG), padahal putusan pengadilan itu bergantung pada undang-undang tersebut;

2) suatu pengadilan menganggap bahwa suatu undang-undang Negara Bagian tidak sesuai dengan (incompatible with) suatu undang-undang Federal;

3) suatu pengadilan, selama berlangsungnya persidangan dalam suatu kasus, merasa ragu apakah suatu ketentuan hukum internasional merupakan bagian dari undang-undang federal dan apakah ketentuan hukum internasional itu secara langsung melahirkan hak dan kewajiban pada individu;

4) Mahkamah Konstitusi dari suatu Negara Bagian, dalam menafsirkan GG, bermaksud menyimpang dari putusan MK Jerman atau putusan Mahkamah Konstitusi Negara Bagian lainnya. ${ }^{20}$

${ }^{19}$ Dikutip dari, Sigrid Born (Ed.), Law on the Federal Constitutional Court (translated by Martin Fry), Inter Nationes, Bonn, 1996, hlm. 34-35.

${ }^{20}$ Sekadar sebagai tambahan informasi, di Jerman, masing-masing Negara Bagian (Länder) juga memiliki Mahkamah Konstitusi, kecuali Negara Bagian Schleswig-Holstein dan Mecklenburg-Vorpommern. Di negara-negara bagian yang disebut terakhir ini, masalah-masalah yang berkait dengan konstitusi diserahkan kepada MK Jerman; lihat Raymond Youngs, English, French \& German Comparative Law, Second Edition, London and New York, RoutledgeCavendish, 2007, hlm. 46. Menurut sejarahnya, mahkamah konstitusi negara bagian lebih dahulu lahir (c.q. mahkamah 
b. Pihak yang mempunyai standing (persona standi in judicio) untuk mengajukan perkara constitutional question adalah:

1) pengadilan "biasa" (regular courts), dalam hal terjadi keadaan sebagaimana disebut pada huruf a angka (1), (2), dan (3) di atas;

2) Mahkamah Konstitusi Negara Bagian, dalam hal terjadi keadaan sebagaimana disebut pada huruf a angka (4) di atas;

c. Pihak yang berwenang memutus perkara constitutional question adalah:

1) pengadilan Negara Bagian yang memiliki kewenangan untuk memutus sengketa konstitusional, jika yang dilanggar oleh undang-undang itu adalah konstitusi Negara Bagian;

2) MK Jerman, untuk kasus-kasus constitutional question selebihnya.

Seluruh kewenangan yang diberikan kepada MK Jerman, baik oleh GG maupun oleh BVerfGG adalah untuk menjamin bahwa semua pihak, terutama pelaksana kekuasaan negara, benar-benar taat kepada Konstitusi $(G G)$ dan benar-benar melaksanakan ketentuan Konstitusi itu dalam praktik. Untuk itulah MK Jerman diberi kewenangan yang begitu luas ruang lingkupnya. Akibatnya, karena demikian luas dan beragamnya kewenangan yang dimiliki oleh MK Jerman, di samping karena MK Jerman bukan merupakan mahkamah banding dari peradilan pada umumnya, maka prosedur beracaranya pun tidaklah sama untuk pelaksanaan masing-masing kewenangan MK Jerman itu. Tidak kurang dari 15 macam prosedur beracara yang berlaku di MK Jerman. Prosedur beracara yang bermacam-macam itu menentukan siapa yang boleh mengajukan permohonan dan siapa yang boleh turut serta di dalamnya. Hal ini merupakan kunci penting dalam setiap kewenangan khusus yang dimiliki MK Jerman. ${ }^{21}$

Ketentuan yang termuat dalam GG maupun BverfGG, yang memberi kewenangan luas kepada MK Jerman itu, dapat juga dilihat dari perspektif yang lain - selain perspektif menjamin ketaatan terhadap Konstitusi - yaitu dari perspektif perlindungan hak-hak konstitusional. Ketentuan dalam GG dan BVerfGG sebagaimana telah dikutip di atas, juga menunjukkan kepada kita bahwa terdapat tiga cara atau prosedur di mana masalah-masalah yang berkenaan dengan

konstitusi Bavaria) daripada Mahkamah Konstitusi Federal atau MK Jerman (Bundesverfassungsgericht). MK Jerman baru terbentuk setelah diterimanya Herrenchiemsee Proposals yang memuat usulan tentang rancangan Konstitusi Federal Jerman sebagai hasil konferensi yang dilangsungkan di danau Chiemsee (Agustus 1948, dan karenanya disebut Herrenchiemsee Conference), setelah mendengar saran-saran dari Prof. Hans Nawiasky yang bekerjasama dengan Pof. Hans Kelsen. Konferensi itu sendiri diikuti oleh negara-negara bagian yang berada di bawah pendudukan Sekutu dan diprakarsai oleh Gubernur Negara Bagian Bavaria, Minister-President Hans Ehard; lihat lebih jauh Donald P. Kommers, Op.Cit., hlm. 7-8.

${ }^{21}$ Helmut Steinberger, "Constitutional Jurisdiction in the Federal Republic of Germany", dalam Journal of Constitutional and Parliamentary Studies, Vol. XVII No. 1-2, January-June, 1983, hlm. 5. 
perlindungan terhadap hak-hak konstitusional dapat diajukan kepada MK Jerman, yaitu::22

1. melalui prosedur yang dikenal sebagai abstract judicial review (abstrakte Normenkontrolle), yaitu proses persidangan yang menyangkut pengujian secara abstrak suatu undang-undang (Pasal 93 Ayat (1) angka 2 GG) ${ }^{23}$ Proses ini terjadi manakala terdapat perbedaan pendapat atau keragu-raguan perihal kebersesuaian, baik formal maupun material, dari suatu undang-undang federal atau undangundang negara bagian dengan konstitusi, atau kebersesuaian suatu undangundang negara bagian dengan undang-undang federal. Prosedur ini dinamakan pengujian abstrak karena untuk dapat mengajukannya tidak dipersyaratkan adanya kasus. Pihak-pihak yang memiliki kedudukan hukum (legal standing) untuk mengajukan permohonan abstrakte Normenkontrolle adalah Pemerintah Federal atau salah satu dari 16 pemerintah negara bagian (Länder) atau sepertiga anggota Parlemen Jerman (Bundestag);

2. melalui prosedur yang dikenal sebagai concrete judicial review (konkrete Normencontrolle), atau constitutional question, yaitu proses persidangan yang mengenai pengujian suatu undang-undang yang relevan dengan suatu kasus hukum tertentu (Pasal 100 Ayat (1) GG). Maksudnya adalah jika suatu pengadilan yakin bahwa undang-undang yang kepadanya putusan atas perkara yang sedang ditanganinya bergantung adalah bertentangan dengan konstitusi maka pengadilan itu tidak boleh mengesampingkan begitu saja undang-undang tersebut melainkan harus menyerahkan persoalan konstitusionalitas undang-undang tersebut kepada MK Jerman dan menghentikan sementara pemeriksaan atas kasus dimaksud sampai ada putusan dari MK Jerman atas konstitusionalitas undang-undang itu. MK Jerman akan menerima seluruh berkas perkara itu namun MK Jerman tidaklah memutus perkara itu sendiri melainkan hanya mengenai konstitusionalitas undang-undang yang dipersoalkan. Setelah adanya putusan dari MK Jerman yang bersifat final dan mengikat semua pengadilan serta badan-badan pemerintahan - maka pengadilan yang mengajukan persoalan konstitusionalitas

${ }^{22}$ Untuk uraian ini, vide lebih jauh Stefan Langer, "The Protection of Fundamental Rights by the Federal Constitutional Court, in particular by way of Constitutional Complaint", Report from Conference on International Experience and Perspectives of Human Rights Protection Before the Constitutional Court, Yerevan, 4-5 October 2002, European Commission for Democracy Through Law (Venice Commission), Strasbourg, 18 December 2002; Victor Ferreres Comella, "Is The European ..., Loc. Cit.

${ }^{23}$ Ketentuan yang relevan juga terdapat dalam Pasal 76 BVerfGG. 
undang-undang itu melanjutkan kembali persidangan mengenai perkara yang bersangkutan dan menjatuhkan putusan sesuai dengan putusan MK Jerman itu. Tentu saja terhadap putusan pengadilan tersebut dapat diajukan banding ke pengadilan yang lebih tinggi yang relevan namun banding tersebut tidak boleh didasari oleh alasan konstitusionalitas karena pertanyaan mengenai konstitusionalitas undang-undang yang berkenaan dengan kasus telah diputus oleh MK Jerman;

3. melalui prosedur pengaduan yang diajukan oleh perorangan yang dinamakan constitutional complaint (Verfassungsbeschwerde) (Pasal 93 Ayat (1) 4a GG). Melalui prosedur ini, setiap orang (termasuk badan hukum privat, sepanjang menyangkut ketentuan Bill of Rights yang juga berlaku terhadapnya) dapat mengajukan permohonan kepada MK Jerman untuk menyatakan suatu undang-undang federal atau undang-undang negara bagian tidak berlaku (void), membatalkan suatu tindakan eksekutif atau administratif atau putusan pengadilan yang lebih rendah, baik pengadilan federal maupun pengadilan negara bagian, dengan alasan adanya pelanggaran terhadap hak-hak orang yang bersangkutan yang dijamin oleh Bill of Rights dalam konstitusi [Pasal 1-17, Pasal 20 Ayat (4), Pasal 33, Pasal 38, Pasal 101, Pasal 103, Pasal 104 GG]. Namun, sebelum mengajukan permohonan demikian, semua upaya hukum yang tersedia telah ditempuh (exhausted).

Suatu pengaduan (complaint) langsung terhadap suatu ketentuan undang-undang dimungkinkan (dalam jangka waktu satu tahun setelah diundangkan) hanya jika orang yang mengadukan (complainant) dapat membuktikan bahwa dirinya sendiri secara langsung dan pada saat itu juga dirugikan oleh ketentuan dimaksud. Hal demikian dapat terjadi, misalnya, suatu undang-undang pemilihan umum yang memuat ketentuan yang hanya memberi kursi kepada suatu partai yang telah memperoleh setidak-tidaknya tujuh persen suara dalam pemilihan umum. ${ }^{24}$ Namun, dalam bagian terbesar, seseorang mungkin dirugikan oleh suatu ketentuan undang-undang melalui perantaraan tindakan administratif atau perbuatan pemerintahan. Misalnya, seorang wajib pajak tidaklah seketika dirugikan oleh ketentuan undang-undang pajak melainkan terutama karena cara penghitungan pajak yang dilakukan berdasarkan ketentuan undang-undang pajak

\footnotetext{
${ }^{24}$ Lebih jauh mengenai contoh kasus dalam uraian ini , vide Hans G. Rupp, "The Federal Constitutional Court and the Constitution of the Federal Republic of Germany", dalam Saint Louis University Law Journal, Vol. 16: 359, hlm. 361 .
} 
itu. Dalam kasus demikian, seorang wajib pajak harus pertama-tama menggugat cara penghitungan pajak itu di pengadilan-pengadilan pajak dengan anggapan atau dalil bahwa cara penghitungan itu didasarkan pada suatu ketentuan undangundang yang bertentangan dengan konstitusi karena, umpamanya, melanggar prinsip perlindungan yang sama (equal protection clause). Constitutional complaint dapat diajukan hanya jika pengadilan-pengadilan pajak dimaksud telah menjatuhkan putusan yang mengalahkan orang yang bersangkutan, dengan anggapan atau dalil bahwa putusan-putusan pengadilan pajak tersebut juga bertentangan dengan prinsip perlindungan yang sama karena pengadilanpengadilan itu telah menerapkan suatu undang-undang yang bertentangan dengan konstitusi. Inilah alasan mengapa constitutional complaint terutama diarahkan kepada putusan-putusan pengadilan. Pengaduan demikian diajukan dalam jangka waktu satu bulan setelah putusan pengadilan itu diucapkan.

Pelanggaran terhadap suatu hak dasar seseorang oleh suatu pengadilan federal atau pengadilan negara bagian dapat terjadi karena salah satu dari tiga hal berikut: (1) putusan itu didasarkan atas suatu ketentuan undang-undang di mana ketentuan undang-undang itu sendiri melanggar suatu hak dasar seseorang; (2) putusan itu didasarkan atas suatu konstruksi yang bertentangan dengan konstitusi sehingga penerapan undang-undang itu sendiri lantas menjadi bertentangan dengan konstitusi; (3) ketentuan undang-undang itu adalah konstitusional, interpretasi dan penerapannya oleh pengadilan juga tidak salah, tetapi proses persidangannya bertentangan dengan due process karena pihak-pihak tidak didengar secara patut [fair hearing, Pasal 103 Ayat (3) GG] atau karena hakim yang menyidangkan kasus itu tidak sah [Pasal 101 Ayat (1) angka 1 GG]. Jika ternyata terbukti bahwa dalil pemohon (complainant) beralasan, maka MK Jerman akan, dalam hal yang disebut pada angka (1), mengubah dan mengembalikan putusan itu kepada pengadilan yang relevan dan pada saat yang sama menyatakan ketentuan undang-undang dimaksud tidak berlaku; dalam hal pada angka (2) dan (3), hanya mengubah putusan dan mengembalikan kasusnya. ${ }^{25}$

Dengan demikian dapat dikatakan bahwa sekalipun putusan pengadilan yang lebih rendah yang terhadapnya diajukan complaint itu telah keliru, MK Jerman tidak dapat menyentuhnya kecuali jika pengadilan yang lebih rendah itu telah melakukan 
kesalahan dalam masalah konstitusional tertentu. Hal demikian dapat terjadi, misalnya, jika pengadilan dimaksud tidak mempertimbangkan bahwa ketentuan undang-undang yang diterapkan itu berubah artinya jika dikonstruksikan dengan mengingat suatu hak dasar yang tersangkut di dalamnya. ${ }^{26}$

Uraian di atas menunjukkan bahwa ketiga prosedur tersebut eksis secara bersama-sama, yang satu tidak meniadakan yang lain. Sehingga, misalnya, tatkala suatu proses persidangan pengujian undang-undang secara abstrak (abstrakte Normenkontrolle) sedang berlangsung di MK Jerman, seorang warga negara yang dirugikan oleh undang-undang itu pada saat yang sama dapat mengajukan permohonan constitutional complaint (Verfassungsbeschwerde). Di samping itu, prosedur constitutional complaint mempunyai makna penting melengkapi konkrete Normenkontrolle, karena jika suatu pengadilan, karena alasan apa pun, tidak memiliki putusan MK Jerman, warga negara yang dirugikan masih memiliki kemungkinan untuk membawa kasusnya ke hadapan MK Jerman melalui prosedur constitutional complaint. Dengan demikian tampak jelas bahwa sistem perlindungan hak-hak asasi manusia melalui MK Jerman hampir dapat dikatakan sempurna. ${ }^{27}$

Dalam hubungan ini, David P. Currie bahkan berkesimpulan bahwa dalam hal upaya menjamin ketaatan yang senyatanya kepada konstitusi dan dalam hal memajukan negara hukum (rule of law), Republik Federal Jerman telah melampaui Amerika Serikat. ${ }^{28}$ Independensi para hakim MK Jerman juga menjadi salah satu faktor penentu dalam hal ini. Meskipun faktor politik ikut berperan dalam pemilihan para hakim MK Jerman, ${ }^{29}$ begitu terpilih mereka harus independen dan hanya tunduk pada hukum. ${ }^{30}$ Namun, untuk sampai pada tingkat independensi yang demikian tinggi, hal itu tidaklah dicapai dengan serta-merta. Sebagaimana dikatakan oleh Prof. Roman Herzog (mantan Presiden MK Jerman) pada pidatonya di Wetzlar tahun 1993, dalam rangka peringatan 300 tahun Reichskammergericht, bahwa sifat non-partisan dan independensi MK Jerman dalam wujudnya saat ini merupakan hasil pencapaian dari abad ke delapan belas dan ke sembilan belas. ${ }^{31}$

\footnotetext{
${ }^{26}$ Ibid.

${ }^{27}$ Stefan Langer, Op.Cit., hlm. 3.

${ }^{28}$ David P. Currie, Op.Cit., hlm. 173.

${ }^{29}$ Menurut Pasal 94 ayat (1) GG, hakim MK Jerman sebagian dipilih oleh Bundestag dan sebagian oleh Bundesrat.

${ }^{30}$ Pasal 97 ayat (1) GG.

${ }^{31}$ Dalam Raymond Youngs, Sourcebook on German Law, Second Edition, London-Sydney-Portland, Cavendish
} Publishing Limited, 2002, hlm. 89. 


\section{Kemungkinan Penerapan Constitutional Question Di Indonesia}

Berbicara tentang kemungkinan penerapan constitutional question di Indonesia berarti berbicara tentang kewenangan Mahkamah Konstitusi Republik Indonesia (selanjutnya disingkat MK). Pertanyaan yang timbul kemudian adalah, jika mekanisme constitutional question itu hendak diadopsi, apakah hal itu serta-merta berarti penambahan kewenangan terhadap MK dari kewenangannya yang selama ini telah secara eksplisit diatur dalam UUD 1945, yaitu Pasal 24C ayat (1) dan (2)?

Sebelum menjawab pertanyaan ini, terlebih dahulu harus diingat bahwa UUD 1945 tegas menyatakan bahwa Indonesia adalah negara demokrasi sekaligus negara hukum, sebagaimana terlihat dari ketentuan Pasal 1 ayat (2) dan (3) UUD 1945. Dua konsekuensi terpenting dari penegasan ini - sesuai dengan prinsip Constitutionalism dan penghormatan, perlindungan, serta pemenuhan hak-hak asasi manusia yang menjadi penanda penting negara demokrasi dan negara hukum - adalah: Pertama, konstitusi (in casu UUD 1945), sebagai hukum tertinggi, harus benar terjelma dan dilaksanakan dalam praktik sehingga seluruh praktik penyelenggaraan kehidupan bernegara tidak boleh bertentangan dengan UUD 1945. Kedua, tatkala hak-hak asasi manusia itu telah dimasukkan ke dalam konstitusi diakui sebagai hak konstitusional warga negara, yang berarti ia telah menjadi bagian dari ketentuan konstitusi, maka seluruh cabang kekuasaan negara terikat untuk menaatinya. ${ }^{32}$

MK dibentuk untuk "mengawal" Konstitusi (UUD 1945). Dengan kata lain, MK dibentuk untuk menjamin bahwa UUD 1945 benar-benar terjelma dan ditaati dalam praktik, termasuk di dalamnya menjamin bahwa hak-hak konstitusional warga negara benar-benar dihormati, dilindungi, dan dipenuhi dalam praktik penyelenggaraan negara. Seluruh kewenangan yang dimiliki MK saat ini, sebagaimana secara limitatif diatur dalam Pasal 24C ayat (1) dan (2) UUD 1945, dapat dikembalikan dan dijelaskan berdasarkan fungsi MK sebagai "pengawal" Konstitusi itu. Namun, yang menjadi pertanyaan, apakah itu cukup - khususnya, dalam konteks seminar ini, dalam hal menjamin penghormatan, perlindungan, dan pemenuhan hakhak konstitusional warga negara?

${ }^{32}$ Lihat lebih jauh Durga Das Basu, Human Rights in Constitutional Law, New Delhi-Nagpur-Agra, Wadhwa and Company, 2003, khususnya hlm. 48-78 dan hlm. 107-135. Sebagai perbandingan, Pasal 1 (3) Konstitusi Jerman $(G G)$, misalnya, dengan tegas menyatakan, "Hak-hak dasar berikut mengikat kekuasaan legislatif, eksekutif, dan yudikatif secara langsung sebagai ketentuan hukum yang dapat dipaksakan" (The following basic rights are binding on legislature, executive, and judiciary as directly enforceable law). 
Dari seluruh kewenangan yang dimiliki MK saat ini, satu-satunya yang langsung berkenaan dengan penghormatan, perlindungan, dan pemenuhan hak konstitusional warga negara adalah kewenangan untuk menguji undang-undang terhadap UUD 1945. Sebab, salah satu alasan yang menyebabkan suatu undang-undang dapat diuji di MK adalah jika undang-undang itu merugikan hak konstitusional warga negara. Pasal 51 ayat (1) Undang-Undang Nomor 24 Tahun 2003 tentang Mahkamah Konstitusi (selanjutnya disebut UUMK) pada intinya menyatakan, antara lain, bahwa yang dapat menjadi Pemohon dalam pengujian undang-undang terhadap UUD 1945 adalah mereka yang hak dan/atau kewenangan konstitusionalnya dirugikan oleh berlakunya suatu undang-undang.

Ada dua hal yang dapat disimpulkan dari ketentuan tersebut. Pertama, pembentuk undang-undang seakan-akan berasumsi bahwa pelanggaran terhadap hak-hak konstitusional itu hanya terjadi karena norma undang-undang. Kedua, pihak yang memiliki standing (persona standi in judicio) untuk mengajukan permohonan pengujian hanya pihak-pihak yang hak konstitusionalnya langsung dirugikan oleh berlakunya undang-undang itu.

Jika kedua hal di atas diperbandingkan dengan praktik yang berlangsung di Jerman, ada beberapa catatan yang dapat kita berikan. Terhadap hal pertama, pelanggaran terhadap hak konstitusional itu juga dapat terjadi karena perbuatan atau kelalaian pejabat publik (public officials atau public authorities). Jadi, bukan sematamata karena ada norma undang-undang yang melanggar hak konstitusional warga negara. Dalam hal pelanggaran itu terjadi karena perbuatan atau kelalaian pejabat publik maka, di Jerman, judicial remedy yang disediakan oleh GG (dan BVertGG) adalah pengaduan konstitusional atau constitutional complaint (Verfassungsbeschwerde). Terhadap hal kedua di atas, jika suatu norma undang-undang bertentangan dengan GG (yang kemungkinan pertentangan itu juga bisa terjadi karena melanggar hak konstitusional warga negara) maka pihak yang boleh mengajukan review ke MK Jerman bukan saja pihak yang secara langsung dirugikan tetapi juga pengadilan, yaitu melalui mekanisme constitutional question atau concrete judicial review (abstrakte normenkontrolle).

Melalui perbandingan dengan praktik di Jerman tersebut terlihat bahwa, meskipun bentuknya berupa pertanyaan (question), konstruksi pemikiran dan substansi yang ada dalam constitutional question di Jerman adalah pengujian undangundang. Oleh karena itu, mekanisme dimaksud sangat memungkinkan untuk 
diadopsi di Indonesia tanpa memerlukan perubahan terhadap UUD 1945. Hal itu cukup dilakukan dengan mengubah UUMK, misalnya dengan menambahkan ketentuan pada Bagian Kedelapan ("Pengujian Undang-Undang terhadap UndangUndang Dasar") bahwa hakim pengadilan dari lingkungan Peradilan Umum, Peradilan Agama, Peradilan Militer, atau Peradilan Tata Usaha Negara, jika dalam memutus suatu perkara yang sedang diadilinya ragu-ragu akan konstitusionalitas undang-undang yang berlaku terhadap perkara itu, dapat mengajukan pertanyaan kepada MK tentang konstitusionalitas undang-undang yang bersangkutan sebelum dijatuhkannya putusan terhadap perkara tersebut. Pemeriksaan terhadap perkara itu dihentikan sementara sampai MK menjatuhkan putusan terhadap konstitusionaltidaknya undang-undang tersebut. Apabila MK menyatakan bahwa undang-undang itu konstitusional atau tidak bertentangan dengan UUD 1945, maka pemeriksaan terhadap perkara tersebut dilanjutkan. Sebaliknya, apabila MK menyatakan bahwa undang-undang yang bersangkutan inkonstitusional atau bertentangan dengan UUD 1945 maka perkara itu dinyatakan gugur demi hukum.

Sesungguhnya hal yang sama juga dapat dilakukan berkenaan dengan pengaduan konstitusional (constitutional complaint). Maksudnya, tanpa perlu melakukan perubahan terhadap UUD 1945 (yang secara limitatif membatasi kewenangan $\mathrm{MK}$ ), mekanisme pengaduan konstitusional pun dapat diadopsi hanya dengan melakukan perubahan terhadap UUMK, meskipun complaint itu terbatas pada tindakan atau kelalaian pejabat publik yang disebabkan oleh kekeliruan dalam menafsirkan maksud yang terkandung dalam norma undang-undang. Caranya adalah dengan menambahkan satu ayat dalam Pasal 56 dan satu ayat dalam Pasal 57 UUMK.

Tambahan ayat dalam Pasal 56 UUMK tersebut, misalnya, berbunyi, “Dalam hal Mahkamah Konstitusi berpendapat bahwa undang-undang yang dimohonkan pengujian, mekipun tidak bertentangan dengan UUD 1945, ternyata telah ditafsirkan sedemikian rupa oleh pejabat publik yang terkait dalam penerapan undang-undang dimaksud sehingga merugikan hak konstitusional warga negara, maka amar putusan menyatakan undang-undang telah ditafsirkan dan diterapkan secara keliru." Ketentuan ini kemudian diikuti oleh tambahan satu ayat dalam Pasal 57 yang berbunyi, misalnya, "Putusan Mahkamah Konstitusi yang amar putusannya menyatakan undang-undang telah ditafsirkan dan diterapkan secara keliru, Mahkamah memerintahkan pemulihan hak atau hak-hak konstitusional warga 
negara yang telah dirugikan oleh kekeliruan penafsiran dan penerapan undangundang dimaksud".

Dalam hubungan dengan usul untuk mengadopsi mekanisme pengaduan konstitusional secara terbatas di atas, ada dua hal yang harus dicermati. Pertama, meskipun substansi permohonan itu sesungguhnya adalah pengaduan konstitusional, permohonan itu sendiri dikonstruksikan sebagai permohonan pengujian undang-undang. Artinya, sama sekali tidak menambah kewenangan Mahkamah Konstitusi yang telah ditentukan secara limitatif oleh UUD 1945. Kedua, permohonan itu hanya dapat dilakukan oleh pihak yang secara faktual telah menderita kerugian hak konstitusional yang disebabkan oleh kekeliruan penafsiran dan penerapan undang-undang. Jadi, berbeda dengan praktik yang selama ini berlangsung di MK, di mana bukan hanya pihak yang secara aktual telah menderita kerugian hak konstitusional tetapi pihak yang (menurut penalaran yang wajar) potensial menderita kerugian konstitusional oleh berlakunya suatu undang-undang pun telah dianggap cukup memenuhi memenuhi syarat untuk bisa diterima legal standing-nya sebagai pemohon, dalam mekanisme pengaduan konstitusional yang diusulkan ini, kerugian faktual merupakan keharusan untuk memenuhi syarat legal standing.

Kembali pada persoalan constitutional question, setidak-tidaknya ada tiga keuntungan penting yang dapat diambil dari penerapan mekanisme constitutional question itu jika hendak diadopsi oleh Indonesia, yaitu:

Pertama, penerimaan mekanisme constitutional question itu akan lebih memaksimalkan penghormatan, perlindungan, dan pemenuhan hak-hak konstitusional warga negara. Sebab, bagi warga negara yang kurang memiliki kesadaran dan/atau kemampuan dalam mempertahankan hak-hak konstitusionalnya yang dijamin Konstitusi (UUD 1945) tetap dapat menikmati pemenuhan hak-hak konstitusionalnya itu tatkala suatu undang-undang, menurut penalaran yang wajar, potensial merugikan hak-hak konstitusionalnya, tanpa yang bersangkutan harus secara aktif mengajukan permohonan pengujian undang-undang itu ke MK.

Kedua, hakim tidak dipaksa menerapkan undang-undang yang berlaku terhadap suatu perkara yang menurut keyakinannya undang-undang itu bertentangan dengan Konstitusi (UUD 1945). Hal demikian tidak dapat dinilai sebagai bentukjudicial activism ataupun dinilai sebagai pelanggaran terhadap prinsip judicial restraint karena alasan dilakukannya tindakan itu adalah untuk menjaga konstitusionalitas undang-undang 
dalam penerapannya yang sekaligus berarti mencegah kemungkinan timbulnya pelanggaran (oleh undang-undang) terhadap hak-hak konstitusional warga negara.

Ketiga, bagi Indonesia yang secara formal maupun tradisi hukum tidak menganut prinsip stare dicisis atau prinsip preseden, hal itu akan membantu terbentuknya kesatuan pandangan atau pemahaman di kalangan hakim-hakim di luar hakim konstitusi mengenai pentingnya menegakkan prinsip konstitusionalitas hukum bukan hanya dalam proses pembentukannya tetapi juga dalam penerapannya.

Salah satu makna hakiki konstitusi, sebagaimana telah diuraikan di atas, adalah menghormati, melindungi, dan memenuhi hak-hak konstitusional warga negara, yang sebagian besar diturunkan dari pengakuan terhadap individual liberty setiap orang. Oleh karenanya, konstitusi hanya akan menjadi konstitusi yang hidup (living constitution) apabila ada kesadaran yang tinggi akan makna konstitusi itu di hati setiap warga negara. Usulan untuk mengadopsi mekanisme constitutional question (juga constitutional complaint), sebagaimana diuraikan di atas, adalah salah satu upaya untuk mendorong makin tumbuhnya kesadaran demikian.

Dalam kaitan itu, sebagai penutup tulisan ini, kiranya kutipan kata-kata mantan Hakim Agung Amerika Serikat, Judge Learned Hand berikut ini dapat lebih meyakinkan kita akan pentingnya kesadaran berkonstitusi itu:

"I often wonder whether we do not rest our hopes too much upon constitutions, upon laws and upon courts. These are false hopes; believe me, these are false hopes. Liberty lies in the hearts of men and women; when it dies there, no constitution, no law, no court can save it; no constitution, no law, no court can even do much to help it. While if it lies there it needs no constitution, no law, no court to save it" ${ }^{\prime \prime 3}$ (Saya kerap merenung jangan-jangan kita telah menaruh harapan terlalu besar pada konstitusi, pada hukum, dan pada pengadilan. Ini hanyalah harapan semu; percayalah, ini hanya harapan semu. Kebebasan sejatinya bersemayam di hati setiap laki-laki dan perempuan; tatkala di situ ia mati, tidak ada konstitusi, tidak ada hukum, tidak ada pengadilan yang mampu menyelamatkannya; bahkan tak banyak yang dapat diperbuat oleh konstitusi, hukum, pengadilan untuk menolongnya. Namun selama kebebasan bersemayam di hati setiap laki-laki dan perempuan, ia tidak membutuhkan konstitusi, ia tidak membutuhkan hukum, ia tidak membutuhkan pengadilan guna menyelamatkannya).

\section{Penutup}

Melalui perbandingan dengan praktik di Jerman terlihat bahwa, meskipun bentuknya berupa pertanyaan (question), konstruksi pemikiran dan substansi yang

${ }^{33}$ Learned Hand, “The Spirit of Liberty”, dalam Herman Schwartz, Op.Cit., hlm. 248. 
ada dalam constitutional question di Jerman adalah pengujian undang-undang. Oleh karena itu, mekanisme dimaksud sangat memungkinkan untuk diadopsi di Indonesia tanpa memerlukan perubahan terhadap UUD 1945. Hal itu cukup dilakukan dengan mengubah UUMK, misalnya dengan menambahkan ketentuan pada Bagian Kedelapan ("Pengujian Undang-Undang terhadap Undang-Undang Dasar") bahwa hakim pengadilan dari lingkungan Peradilan Umum, Peradilan Agama, Peradilan Militer, atau Peradilan Tata Usaha Negara, jika dalam memutus suatu perkara yang sedang diadilinya ragu-ragu akan konstitusionalitas undang-undang yang berlaku terhadap perkara itu, dapat mengajukan pertanyaan kepada MK tentang konstitusionalitas undang-undang yang bersangkutan sebelum dijatuhkannya putusan terhadap perkara tersebut. Pemeriksaan terhadap perkara itu dihentikan sementara sampai MK menjatuhkan putusan terhadap konstitusional-tidaknya undang-undang tersebut. Apabila MK menyatakan bahwa undang-undang itu konstitusional atau tidak bertentangan dengan UUD 1945, maka pemeriksaan terhadap perkara tersebut dilanjutkan. Sebaliknya, apabila MK menyatakan bahwa undang-undang yang bersangkutan inkonstitusional atau bertentangan dengan UUD 1945 maka perkara itu dinyatakan gugur demi hukum.

\section{Daftar Pustaka}

Baker, Ernest, Reflection on Government, Oxford, Oxford University Press, 1958

Basu, Durga Das, Human Rights in Constitutional Law, Wadhwa and Company, New Delhi-Nagpur-Agra, 2003.

Born, Sigrid (Ed.), Law on the Federal Constitutional Court (translated by Martin Fry), Inter Nationes, Bonn, 1996.

Brown, Trevor L.\& Charles R. Wise, "Constitutional Courts and Legislative-Executive Relations: The Case of Ukraine", Political Science Quarterly, Vol. 119, No. 1, 1994.

Cappelletti, Mauro, The Judicial Process in Comparative Perspective, Oxford, Clarendon Press, 1989

Comella, Victor Ferreres, "Is the European Model of Constitutional Review in Crisis", paper presented for the $12^{\text {th }}$ Annual Conference on 'the Individual Vs. the State', Central European University, Budapest, June 18-19, 2004.

Comella, Victor Ferreres, “The Conssequences of Centralizing Constitutional Review in A Special Court: Some Thoughts on Judicial Activism" dalam http:/ / www.utexas.edu/law/journals/tlr/abstracts/82/ 82ferreres.pdf. 
Currie, David P., The Constitution of the Federal Republic of Germany, Chicago and London, the University of Chicago Press, 1994.

Ferejohn, John \& Pasquale Pasquino, "Rule of Democracy and Rule of Law" dalam Josë María Maravall \& Adam Przeworski, , Democracy and Rule of Law, Cambridge, Cambridge University Press, 2003.

Green, Michael, "Hans Kelsen and the Logic of Legal System" dalam Alabama Law Review Volume 54, Number 2, Winter 2003.

Hausmaninger, H., 2003, The Austrian Legal System, Manzsche Verlags- und Universitätsbuchhandlung: Wien.

Hess, Frederick W. (Ed.), German Unity, Documentation and Commentaries on the Basic Treaty, East Europe Monograph 4, Park College, Govermental Research Bureau, Kansas City-Missouri.

Horowitz, Donald L., “Constitutional Courts: A Primer for Decision Makers" dalam Journal of Democracy, Volume 17, Number 4, October 2006.

Jimly Asshiddiqie, Model-model Pengujian Konstitusional Di Berbagai Negara, Cetakan Kedua, Jakarta, Konpres, 2005.

Kommers, Donald P., The Constitutional Jurisprudence of the Federal Republic of Germany, Durham and London, Duke University Press, 1989.

Kritzer, Herbert M. (ed.), Legal Systems of the World, A Political, Social and Cultural Encyclopedia, Volume I: A-D, New Delhi, Pentagon Press, 2005.

Langer, Stefan, "The Protection of Fundamental Rights by the Federal Constitutional Court, in particular by way of Constitutional Complaint", Report from Conference on International Experience and Perspectives of Human Rights Protection Before the Constitutional Court, Yerevan, 4-5 October 2002, European Commission for Democracy Through Law (Venice Commission), Strasbourg, 18 December 2002.

I Dewa Gede Palguna, Mahkamah Konstitusi, Judicial Review, dan Welfare State, Jakarta, Sekretariat Jenderal dan Kepaniteraan Mahkamah Konstitusi RI, 2008.

Rupp, Hans G., "The Federal Constitutional Court and the Constitution of the Federal Republic of Germany", dalam Saint Louis University Law Journal, Vol. 16: 359.

Schwartz, Herman, The Struggle for Constitutional Justice in Post-Communist Europe, the University of Chicago Press: Chicago and London, 2000.

Steinberger, Helmut, "Constitutional Jurisdiction in the Federal Republic of Germany", dalam Journal of Constitutional and Parliamentary Studies, Vol. XVII No. 1-2 (January-June, 1983).

Tschentscher, Axel, The Basic Law (Grundgesetz), Wurzburg, Jurisprudentia Verlag, 2002.

Youngs, Raymond, Sourcebook on German Law, Second Edition, London-Sydney-Portland, Cavendish Publishing Limited, 2002.

Youngs, Raymond, English, French \& German Comparative Law, Second Edition, London and New York, Routledge-Cavendish, 2007. 
